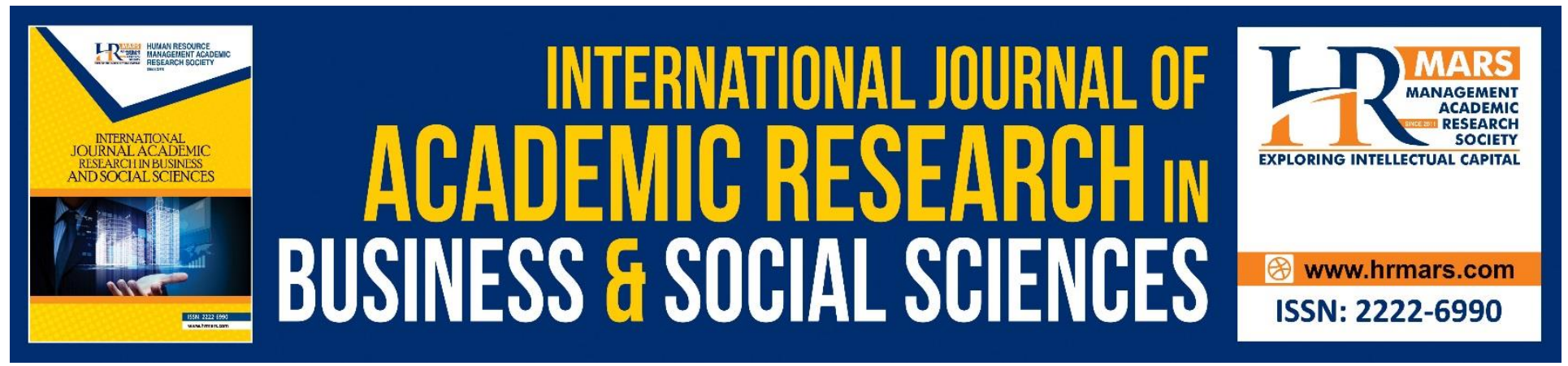

\title{
Restaurant Operators' Level of Knowledge, Attitude and Practice (KAP) Towards Reheated Cooking Oil (RCO) in Association with Total Polar Compound (TPC) and Acid Value (AV)
}

Amanina Abd Rahman, Zuraini Mat Issa, Norhidayah Abdullah

To Link this Article: http://dx.doi.org/10.6007/IJARBSS/v11-i13/8506

DOI:10.6007/IJARBSS/v11-i13/8506

Received: 11 November 2020, Revised: 02 December 2020, Accepted: 25 December 2020

Published Online: 20 January 2021

In-Text Citation: (Rahman et al., 2021)

To Cite this Article: Rahman, A. A., Issa, Z. M., \& Abdullah, N. (2021). Restaurant Operators' Level of Knowledge, Attitude and Practice (KAP) Towards Reheated Cooking Oil (RCO) in Association with Total Polar Compound (TPC) and Acid Value (AV). International Journal of Academic Research in Business and Social Sciences, 11(13), 116-126.

Copyright: (c) 2021 The Author(s)

Published by Human Resource Management Academic Research Society (www.hrmars.com)

This article is published under the Creative Commons Attribution (CC BY 4.0) license. Anyone may reproduce, distribute, translate and create derivative works of this article (for both commercial and non-commercial purposes), subject to full attribution to the original publication and authors. The full terms of this license may be seen

at: http://creativecommons.org/licences/by/4.0/legalcode

Special Issue: Beyond 2021 and COVID-19 - New Perspective in the Hospitality \& Tourism Industry, 2021, Pg. 116 - 126

Full Terms \& Conditions of access and use can be found at http://hrmars.com/index.php/pages/detail/publication-ethics 


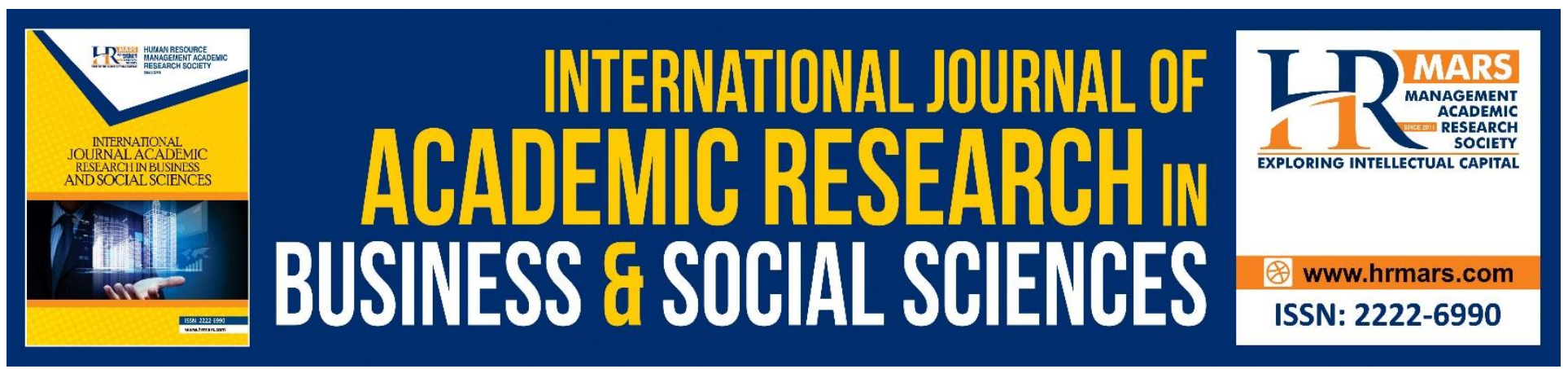

\title{
Restaurant Operators' Level of Knowledge, Attitude and Practice (KAP) Towards Reheated Cooking Oil (RCO) in Association with Total Polar Compound (TPC) and Acid Value (AV)
}

\author{
Amanina Abd Rahman, Zuraini Mat Issa, Norhidayah Abdullah \\ Faculty of Hotel and Tourism Management, Universiti Teknologi MARA, Puncak Alam Campus, \\ 42300, Selangor, Malaysia
}

\begin{abstract}
This paper aims to investigate the level of knowledge, attitude and practice of RCO usage of restaurant operators in the capital city of Shah Alam. In addition, to investigate the quality of cooking oil used by these restaurant operators, samples of cooking oil are collected and tested using established cooking oil quality parameters. Cooking oil quality can be measured by Total Polar Compound (TPC) and Acid Value (AV) tests. Testo 270 is a tool that helps to determine the concentration level of degraded products in cooking oil and can be used to evaluate the TPC level in cooking oil. 3M Long range shortening monitor (LRSM) is a test strip that measures the free fatty acid (FFA) levels in cooking oil. These two rapid test kits enable cooking oil quality to be measured quickly by analysing their chemical parameters. High TPC and FFA value indicate that the quality of cooking oil is harmful for consumption. This article aims to highlight the level of restaurant operators' KAP towards usage of RCO, and KAP association with the quality of cooking oil used.
\end{abstract}

Keywords: Reheated Cooking Oil, Frying, Restaurant Operators, Total Polar Compound, Acid Value, Health, Knowledge, Attitude and Practice.

\section{Introduction}

Studies found that the foodservice industry in many urban areas of developing nations throughout the world are enjoying an increase in patronage (Alimi, 2016). This is contributed to the expansion of urban population growth and the growing trend of eating out (Alimi, 2016; Azman, Shahrul, Chan, Noorhazliza, Khairunnisak, Azlina, Qodriyah, Kamisah \& Jaarin, 2012; Shahidan, 2015). Similarly, this trend has also been observed to be growing in Malaysia (Ahmad, 2015). Malaysia is a developing country, growing in population. As rural migration and expansion of urban boundaries with formation of new townships rise, people's eating behaviour changes, along with their lifestyles. 
Working parents in urban households contribute to the reduced time urbanites have to spend preparing meals and to dine at home (Ali \& Abdullah, 2012). In Malaysia today, food is plentiful and easily available, thus, motivating dual-income households to opt for takeaways and home deliveries. In addition, rapid urban growth has stimulated a rise in the need for inexpensive and instant meals. Data collected by Poulain, Laporte, Smith and Tibere (2015) showed $47.7 \%$ of Malaysian meals are from eating out and purchasing takeaway food, with $61.6 \%$ Malaysians having at least one meal purchased daily.

Among the most common cooking preparation methods opted by Malaysian foodservice operators is frying. Frying contributes to enhancing properties in food, such as heightening the complexity of flavour, bringing out the appealing colour and giving fried food its distinctive texture and crispiness (Choe \& Min, 2007; Nayak, Dash, Rayaguru \& Krishnan, 2016). Another appeal for using frying as a cooking method in food business ventures includes less equipment and space the method requires compared to other cooking methods (Azman et al., 2012; Shahidan, 2015). However, the quality of fried food is highly influenced by the quality of the cooking oil in which it is fried (Kalogianni et. al., 2016).

When food is fried, a series of chemical reactions occur which cause cooking oil's chemical compound to break down and this increases the oil's oxidation rate. The chemical changes in cooking oil also affect the physical characteristics of the oil and the fried food produced, such as, causing the colour of cooking oil to darken, increasing its viscosity and froth, as well as, causing the reduction of cooking oil's smoking point (Ganesan et al., 2019). Reheating cooking oil (RCO) further accelerates formation of oxidized and polymerized lipid species in the frying medium, thus, promoting further cooking oil quality deterioration (Perumalla \& Subramanyam, 2016).

RCO consumption has been validated to be detrimental to health by numerous studies. The practice of RCO has been linked to causing genotoxic, mutagenic and carcinogenic potentials, along with, promoting increased blood pressure (Ganesan et al., 2019; Leong, Ng, Jaarin \& Mustafa, 2015; Perumalla \& Subramanyam, 2016). According to Aziz, Elias, and Sabran (2018), and Kalogianni et al. (2016), it is a common practice among Malaysian food operators to reheat cooking oil and to fry food repeatedly using the same oil for several days. These studies also suggest food operators use RCO mainly to try cut down expenses. With the booming restaurant sector in Malaysia, there is hence, a need to study restaurant food operators' knowledge on harmful effects of RCO, as well as, their attitude and practice of RCO.

\section{Literature Review \\ Reheated Cooking Oil (RCO)}

Reheated cooking oil (RCO) refers to the practice of reusing cooking oil in multiple frying sessions (Leong et al., 2015). Cooking oil primarily serves as the medium of heat exchange; however; as much as $45 \%$ of oil ends up in the final fried product (Orthoefer \& List, 2007). Therefore, the quality of cooking oil has to be properly maintained throughout the cooking process to ensure good fried food quality. Frying of food should not be heated above $180^{\circ} \mathrm{C}$, for any longer than 24 hours of continuous heating (Chen, Chiu, Cheng, Hsu, \& Kuo, 2013). When cooking oil is reheated excessively, the chemical 
reactions enhance, causing rapid degradation to the cooking oil both chemically and physically (Leong et al., 2015).

According to Bordin, Kunitake, Aracava and Trindade (2013), extended exposure of cooking oil to high temperatures and air can lead to highly oxidized and toxic products to form and accumulate in the cooking oil. Additionally, it alters the structure of proteins, vitamins and antioxidants, as well as, nutrients in food. Cooking oil deteriorates in quality and loses its nutritive value with repeated frying. Thus, these cooking oil is supposed to be discarded when its chemical and physical properties show any adverse effect on the organoleptic properties of the fried food product (Wai, 2007). Nevertheless, Malaysian food operators often practise reheating their cooking oil repeatedly for days to cut cost (Aziz et al., 2018; Azman et al., 2015; Kalogianni et al., 2016; Phiri et al., 2006).

\section{Health Issues Related to Consumption of RCO}

Chemical reactions during frying ultimately alter the physical and chemical properties of the cooking oil, degrading the oil each time it is reheated (Park \& Kim, 2016). Formation of cooking oil degradation products such as hydro peroxide, short chain acid, ketones, alcohol and aldehydes accumulate as frying time lengthens, increasing the toxic compound in cooking oil (Shahidan, 2015). These accumulated compounds are then absorbed into the fried food (Jaarin \& Kamisah, 2012) which can later lead to implications to health by destroying vitamins, inhibiting enzyme production and causing gastrointestinal irritations, as well as, mutations (Bhuiyan et al., 2016).

When cooking oil is repeatedly reheated, it becomes more vulnerable to lipid peroxidation, thus, inducing oxidative stress in endothelial cells, which may lead to endothelial dysfunction, increasing the risk of developing atherosclerosis (Perumalla \& Subramanyam, 2016). Soriguer et al. (2003) supported this point of view and have stated that the presence of surplus polar compound in RCO showed to be connected to promote risk of hypertension, cardiovascular diseases (CVD) (Subermaniam, Saad, Das \& Othman, 2014) and malignancies, such as lung, colorectal, breast, and prostate cancers (Ganesan et al., 2019).

The application of RCO when frying food not only affects consumers' health, but also affects the heath of food operators. RCO is found to emit highly oxidised oils during frying that may generate polycyclic aromatic hydrocarbon (PAH) and aldehydes, which have been reported to have carcinogenic effects (Bhuiyan, M., Khan, M., Rahman, A., \& Chowdhury, 2016; Ganesan et al., 2019; Wu, Lin, Pan \& Peng, 2019). Several studies suggested inhalation of RCO fumes promote genotoxic (Dung, Wu, \& Yen, 2006), mutagenic and carcinogenic activities in the human body (Purcaro et. al., 2006; Srivastava et al., 2010).

\section{Food Operators' Knowledge, Attitude and Practice towards Reheated Cooking Oil}

According to Wan et. al (2016), "Knowledge" can be gained through education or experience whereby further understanding and facts are explored beyond the emotional experience. It is the combination of experience, judgment and skill by demonstrating an individual's ability to pursue, retain and use information attained. "Attitude" evaluates an individual's psychological predisposition to act on information based on their degree of favour or disfavour towards a subject, to predict one's behaviour (Wan et al., 2016). To be put simply, it is a mental state of readiness to respond to a 
situation. "Practice" is equated to action led by knowledge and the attitude of adherence to rules, to protect against possible problems (Badran, 1995). Therefore, practice can be viewed as an indicator of knowledge and attitude, working together.

Knowledge is an important feature in any foodservice business venture. Equipping food operators with proper guidelines and information on potential harm regarding RCO usage may encourage a more concerned attitude towards the practice of using RCO. According to Asmawi et al. (2018), food operators have demonstrated poor knowledge on food safety management and handling of food. Studies conducted by Asmawi et al. (2018), Azman et al. (2012) and Sivananthan et al. (2013) show Malaysian food operators still lack in knowledge of RCO usage. A study conducted by Azman (2012) suggests food operators have some basic knowledge on potential risk of RCO as $67 \%$ of the study's respondents did not agree to the practice of using RCO. Sharkawi, Mohamed and Rezai (2014) and Bhattacharya (2010) studies stated that limited information is given out to the food operators on guidelines on how reuse cooking oil and how to monitor the practice of RCO. A survey conducted by Azman, et al. (2012) concluded that although food operators were largely aware that RCO practice was unhealthy, they did not understand exactly why.

Attitude is an important factor in the enforcement of practice. A previous study by Azman et al. (2012) suggests attitude towards usage of RCO is influenced by the idea that degraded cooking oil effects the quality of fried food. The study found 37 night market operators who claimed to not use RCO perceived that RCO can heavily affect the quality and the physical attractiveness of fried food in terms of colour, texture and taste. One factor that may influence food operators' to use RCO is the fear of rising production cost (Azman et al., 2012; Nayak et al., 2016). In addition, Wai (2007) suggested RCO practice among food operators is contributed to them being unaware of the proper disposing method of used cooking oil. In the study by Azman et al. (2012), it was found that food operators still practised RCO even though they disagreed that cooking oil quality could remain unchanged after being repeatedly heated.

A prior study by Asmawi et al. (2018) concluded food operators' practice is influenced by knowledge and attitude. However, the study by Azman et al. (2012) found knowledge and attitude were not reflected in their practice. Azman et al. (2012) revealed street-food operators (63.0\%) admitted to use RCO for deep frying despite having scored favourably in knowledge and attitude towards RCO. In another study, Aziz et al. (2018) claimed food operators still practised RCO to cut cost even though they were aware of the negative health effects of RCO. These studies also highlighted that although majority of the respondents had attended food safety training, on average, food operators' practice towards the usage of RCO is still poor.

\section{Total Polar Compound (TPC) as Parameters to Indicate Cooking Oil Quality}

Shahidan (2015) stressed that it is necessary to monitor the quality of cooking oil to avoid harmful health effects and unacceptable quality of fried foods. Sensory and physical tests are generally relied on by food operators to assess the extent of cooking oil degradation, which usually includes foam and smoke formation, darkening of colour, viscosity and odour. However, using the naked eye is insufficient to determine the degradation of used cooking oil (Aziz et al., 2018). Hence, to evaluate 
the deterioration extent of cooking oil, parameters can be used to determine the concentration level of cooking oil's degraded products (Osawa, Gonçalves, Gumerato, \& Mendes, 2012). In international regulations, two most widely used chemical parameter for oil quality are the TPC and AV (Chen et al., 2013).

During heat treatment of food, oil undergoes chemical reactions of hydrolysis, oxidation, and polymerization. These reactions form TPC. TPC consists of decomposition products namely, short chain fatty acid, aldehydes, ketones, alcohol and non-volatile products (Khor et al., 2019). These decomposition products cause undesirable odour, unpleasant colour and high viscosity in cooking oil. Repeated frying accelerates degradation of cooking oil, subsequently, resulting in an increase in the number of polar molecules further enhancing the degradation of fried food quality (Clark \& Serbia, 1991).

Therefore, determining the level of TPC in cooking oil is a good indicator to measure cooking oil quality. TPC value determination is accepted as the best known reliable indicator to assess the extent of oxidative degradation content and evaluate cooking oil quality (Hampikyan et al., 2011; Chen et al., 2013; Dobarganes et al., 2000). The International legislation has determined that the safe limit or Upper Limit (UL) of TPC content is 25 percent (Chen et al., 2013; Osawa et al., 2012). When the TPC content of cooking oil reaches 25 percent, it is considered unsafe for consumption and it is therefore, advised to be discarded (Chen et al., 2013). Testo 270 is a tool that measures TPC content in cooking oil. Application of Testo 270 device allows the detection of dielectric constant in cooking oils, and this constant can be converted to TPC content (\%) (Chen et al., 2013).

\section{Acid Value (AV) as a Parameter for Indicating Cooking Oil Quality}

Free fatty acid (FFA) is suggested to be the main determinant of the degree of hydrolysis and an indicator of cooking oil deterioration (Tarmizi, Ismail \& Kuntom, 2016). For cooking oil, the AV test is one of the methods used to investigate the quality of cooking oil by evaluating the level of FFA compounds (Chen et al., 2013). It measures the content of FFAs that are freed from their ester linkage from the parent triglyceride molecule (Shaik, 2008). FFA is formed by hydrolysis of oils and fats at high temperature, thereby making FFA more vulnerable to oxidative degradation and to turn rancid (Nayak et al., 2016). Presence of FFA in cooking oil is associated with undesirable darkening of colour, offflavour and lowering of cooking oil smoke point. All these reactions degrade commercial value of cooking oil (Mahesar et al., 2014).

Additionally, the FFA contents increase with the frequency of frying. High levels of FFA in cooking oil indicates the degree of cooking oil degradation. Therefore, FFA is a reliable indicator to monitor the quality of cooking oil (Choe \& Min, 2007). Rapid test kit, 3M Long range shortening monitor (LRSM) is a rapid tool that provides an indication index of FFA concentration range of cooking oil by measuring the acidity of oil sample by $3 \mathrm{M}$, United State. It is reported by Kalogianni et al. (2016) that this test is easy to use, rapid and safe. 


\section{Methodology}

World Health Organization (WHO) (2008) suggests that using the knowledge, attitude and practice (KAP) survey model helps to reveal a community's understandings, perceptions and habits towards health-related issues. Developed in 1950, the KAP survey is an established baseline or reference tool to study human behaviour and KAP survey also allows assessment of the extent of a community's current health issues (Wan, Rav-Marathe \& Marathe, 2016; Memon et al., 2015). Therefore, by using KAP survey model, this study aims to examine the association between KAP on quality of cooking oil among restaurant food operators with regards to RCO practices.

Along with KAP modal, this study will also evaluate the quality of cooking oils. Chemical parameters can be used to evaluate the level of polar compounds in cooking oil to assess the extent of oil degradation. The quality of cooking oil collected from restaurants will be measured by TPC test and AV test. According to Chen et al (2013) and Kalogianni et al. (2016), the TPC and AV tests are prominent indicators of cooking oil quality. Testo 270 and LRSM test strips will be used in this study to measure the chemical parameters of TPC and FFA.

Considering that this study uses the KAP survey modal and collects cooking oil samples from restaurant operators, quantitative study method will be employed. Questionnaires will be distributed by selfadministration. Cooking oil sample will be collected in one liter. The cooking oil sample will be carefully marked and kept in a glass jar at low temperature, as well as, in a dark container to prevent further degradation. Analysis of cooking oil TPC and AV will be done in lab using Testo 270 and 3M LRSM respectively in triplicates. Analysis of data will answer the study objectives and hypotheses.

\section{Conclusion}

This study contributes to further understanding of restaurant operators' KAP towards the usage of RCO in association with the quality of cooking oil. Significance of this study can be categorized into two aspects. From the industry perspective, this study is beneficial to improve restaurant operators' awareness on proper implementation of RCO usage. Quality of fried food depends heavily on the quality of cooking oil used. Hence, awareness of proper usage on RCO can promote improvement of the quality of fried food sold. Furthermore, this study will provide the latest data on Shah Alam restaurant operators' KAP towards RCO usage. Consequently, this enables the local health authorities to have insights to assist in improving their policies and regulations on the usage of RCO. Findings obtained from this research can be imperative to assist future researches, create future awareness campaigns on RCO practices and can be beneficial for the local municipality to develop impactful policies and effective measures to limit usage of degraded RCO among food operators.

In addition, restaurant operators' awareness on harmful effects of RCO can prevent the practice of overly RCO. Information collected in this study can also aid in developing campaigns related to awareness on the dangers of RCO for food business ventures. This is because there is currently no regulation to enforce monitoring on the appropriate usage of RCO. This study may provide a practicable guide in assisting the government, like the Ministry of Health, and the local municipal authority to improve food operators' level of KAP towards the quality of cooking oil. 


\section{Academic Contribution}

On the academic aspect, due to the scarcity of studies looking into RCO usage, this study may help to bridge the gap of knowledge of food operators' KAP with their usage of RCO. Hence, this study will present in-depth understanding on the importance of monitoring the usage of RCO in the foodservice industry. This, in turn, allows recommendations to be made on how to improve and maintain correct practice of RCO among food operators who use frying method. This study will also help widen opportunity for further exploration on RCO practices in different study settings. Insights obtained from this study may directly contribute towards the extension of the Malaysian food operators' body of literature.

\section{Acknowledgement}

This paper was made possible through the generous support of Universiti Teknologi MARA, Malaysia (UiTM).

\section{Corresponding Author}

Rahman Amanina Abd. Faculty of Hotel and Tourism Management, Universiti Teknologi MARA, Puncak Alam Campus, 42300, Selangor, Malaysia.

E-mail: amanina.abdrahman@gmail.com

\section{Reference}

Ahmad, F. (2015). Influence of Demographic, Food Attributes, Physical Environment and Service Attributes on Perceived Value and Overall Satisfaction At Casual Dining Restaurants in Klang Valley, Malaysia.

Ali, N., \& Abdullah, M. A. (2012). The food consumption and eating behaviour of Malaysian urbanites: Issues and concerns. Geografia - Malaysian Journal of Society and Space, 8(6).

Alimi, B. A. (2016). Risk factors in street food practices in developing countries: A review. Food Science and Human Wellness, 5(3), 141-148. https://doi.org/10.1016/j.fshw.2016.05.001

Asmawi, U. M. M., Norehan, A. A., Salikin, K., Rosdi, N. A. S., Munir, N. A. T. A., Basri, N. B. M., ... Nor, N. M. (2018). An assessment of knowledge, attitudes and practices in food safety among food handlers engaged in food courts. Current Research in Nutrition and Food Science, 6(2), 346353. https://doi.org/10.12944/CRNFSJ.6.2.09

Aziz, A. A., Elias, S. M., \& Sabran, M. R. (2018). Repeatedly Heating Cooking Oil among Food Premise Operators in Bukit Mertajam, Pulau Pinang and Determination of Peroxide in Cooking Oil. Malaysian Journal of Medicine and Health Sciences, 14(6), 37-44.

Azman, A., Mohd Shahrul, S., Chan, S. X., Noorhazliza, A. P., Khairunnisak, M., Nur Azlina, M. F., ... Jaarin, K. (2012). Level of knowledge, attitude and practice of night market food outlet operators in Kuala Lumpur regarding the usage of repeatedly heated cooking oil. Medical Journal of Malaysia, 67(1), 91-101.

Azman, A., Mohd Shahrul, S., Xuan, C. S., Patah, N. A., Mokhtar, K., Mohd Fahami, N. A., ... Jaarin, K. (2015). Awareness regarding the usage of repeatedly heated cooking oil in Kuala Lumpur, Malaysia. Research Journal of Pharmaceutical, Biological and Chemical Sciences, 6(1), 184-195.

Badran, I. G. (1995). Knowledge, attitude and practice the three pillars of excellence and wisdom: a place in the medical profession. EMHJ - Eastern Mediterranean Health Journal, 1(1), 8-16. 
Bhuiyan, M., Khan, M., Rahman, A., \& Chowdhury, U. . (2016). Effect of Reheating on Thermophysical Properties of Edible Oil at High Temperature. International Journal of Advanced Research in Physical Science (IJARPS), 3(2), 30-34.

Bordin, K., Kunitake, M. T., Aracava, K. K., \& Trindade, C. S. F. (2013). Changes in food caused by deep fat frying - A review. Archivos Latinoamericanos de Nutricion, 63(1), 5-13.

Chen, W. A., Chiu, C., Cheng, W.-C., Hsu, C.-K., \& Kuo, M.-I. (2013). Total polar compounds and acid values of repeatedly used frying oils measured by standard and rapid methods. Journal of Food and Drug Analysis, 21(1), 58-65. https://doi.org/10.6227/jfda.2013210107

Choe, E., \& Min, D. B. (2007). Chemistry of deep-fat frying oils. Journal of Food Science, 72(5). https://doi.org/10.1111/j.1750-3841.2007.00352.x

Dobarganes, M. C., Velasco, J., \& Dieffenbacher, A. (2000). Determination of polar compounds, polymerized and oxidized triacylglycerols, and diacylglycerols in oils and fats: Results of collaborative studies and the standardized method (Technical report). Pure and Applied Chemistry, 72(8), 1563-1575. https://doi.org/10.1351/pac200072081563

Dung, C. H., Wu, S. C., \& Yen, G. C. (2006). Genotoxicity and oxidative stress of the mutagenic compounds formed in fumes of heated soybean oil, sunflower oil and lard. Toxicology in Vitro, 20(4), 439-447. https://doi.org/10.1016/j.tiv.2005.08.019

Ganesan, K., Sukalingam, K., \& Xu, B. (2019). Impact of consumption of repeatedly heated cooking oils on the incidence of various cancers- A critical review. Critical Reviews in Food Science and Nutrition, 59(3), 488-505. https://doi.org/10.1080/10408398.2017.1379470

Kalogianni, E. P., Georgiou, D., Romaidi, M., Exarhopoulos, S., Petridis, D., Karastogiannidou, C., ... Karakosta, P. (2016). Rapid Methods for Frying Oil Quality Determination: Evaluation with Respect to Legislation Criteria. JAOCS, Journal of the American Oil Chemists' Society, 94(1), 1936. https://doi.org/10.1007/s11746-016-2919-1

Khor, Y. P., Hew, K. S., Abas, F., Lai, O. M., Cheong, L. Z., Nehdi, I. A., ... Tan, C. P. (2019). Oxidation and polymerization of triacylglycerols: In-depth investigations towards the impact of heating profiles. Foods, 8(10), 1-15. https://doi.org/10.3390/foods8100475

Leong, X.-F., Ng, C.-Y., Jaarin, K., \& Mustafa, M. (2015). Effects of Repeated Heating of Cooking Oils on Antioxidant Content and Endothelial Function. Austin Journal of Pharmacology and Therapeutics, 3(2), 1068.

Mahesar, S., Sherazi, S. T., Khaskheli, A., Kandhro, A., \& Uddin, S. (2014). Analytical Approaches for free fatty acids assessment in oils and fats. Analytical Method, 6(14). https://doi.org/10.1039/c4ay00344f

Memon, M. S., Shaikh, S. A., Shaikh, A. R., Fahim, M. F., Mumtaz, S. N., \& Ahmed, N. (2015). An assessment of knowledge, attitude and practices (KAP) towards diabetes and diabetic retinopathy in a suburban town of Karachi. Pakistan Journal of Medical Sciences, 31(1), 183188. https://doi.org/10.12669/pjms.311.6317

Nayak, P. K., Dash, U., Rayaguru, K., \& Krishnan, K. R. (2016). Physio-Chemical Changes During Repeated Frying of Cooked Oil: A Review. Journal of Food Biochemistry, 40(3), 371-390. https://doi.org/10.1111/jfbc.12215

Organization, W. H. (2008). Advocacy, communication and social mobilization for TB control: a guide to Guide To Developing Knowledge, Attitude and Practice Surveys. 
Osawa, C. C., Gonçalves, L. A. G., Gumerato, H. F., \& Mendes, F. M. (2012). Study of the effectiveness of quick tests based on physical properties for the evaluation of used frying oil. Food Control, 26(2), 525-530. https://doi.org/10.1016/j.foodcont.2012.01.008

Perumalla, V., \&, \& Subramanyam, R. (2016). Evaluation of the deleterious health effects of consumption of repeatedly heated vegetable oil. Toxicology Reports, 3, 636-643. https://doi.org/10.1016/j.toxrep.2016.08.003

Phiri, G., Mumba, P., \& Mangwera, A. (2006). The quality of cooking oil used in informal food processing in Malawi: A preliminary study. International Journal of Consumer Studies, 30(6), 527-532. https://doi.org/10.1111/j.1470-6431.2006.00513.x

Poulain, J. P., Smith, W., Laporte, C., Tibère, L., Ismail, M. N., Mognard, E., Aloysius, M., Neethiananthan, A. B, Shamsul, A. B. (2015). Studying the consequences of modernization on ethnic food patterns: Development of the Malaysian Food Barometer (MFB). Anthropology of Food.

Purcaro, G., Navas, J. A., Guardiola, F., Conte, L. S., \& Moret, S. (2006). Polycyclic aromatic hydrocarbons in frying oils and snacks. Journal of Food Protection, 69(1), 199-204. https://doi.org/10.4315/0362-028X-69.1.199

Shahidan, F. S. (2015). Determination of Peroxide Value in Deep-Frying Oil Collected at Night Market in Kepala Batas. Universiti Sains Malaysia, 1(30), 77-87.

Shaik, R. (2008). Analytical Tool for Rapid Analysis of Edible Oil. 121. Retrieved from http://projekter.aau.dk/projekter/files/14459699/thesis_20abstract12_1_complete.pdf

Sivananthan, M., Elamaran, M., Jasmin, K., \& Kushha, R. (2013). Level of knowledge, attitude and practice of food outlet operators in Raub, Pahang morning market regarding the usage of repeatedly heated cooking oil-A cross sectional study. International Journal of Biomolecules and Biomedicine, 3(3), 2221-1063. Retrieved from http://www.innspub.net

Soriguer, F., Rojo-Martínez, G., Dobarganes, M. C., García Almeida, J. M., Esteva, I., Beltrán, M., ... González-Romero, S. (2003). Hypertension is related to the degradation of dietary frying oils. American Journal of Clinical Nutrition, 78(6), 1092-1097.

https://doi.org/10.1093/ajcn/78.6.1092

Srivastava, S., Singh, M., George, J., Bhui, K., \& Shukla, Y. (2010). Genotoxic and carcinogenic risks associated with the consumption of repeatedly boiled sunflower oil. Journal of Agricultural and Food Chemistry, 58(20), 11179-11186. https://doi.org/10.1021/jf102651n

Subermaniam, K., Saad, Q. H. M., Das, S., \& Othman, F. (2014). Virgin Coconut Oil (VCO) Decreases the Level of Malondialdehyde (MDA) in the Cardiac Tissue of Experimental Sprague-Dawley Rats Fed with Heated Palm O. Journal of Medical and Bioengineering, 3(2), 102-106. https://doi.org/10.12720/jomb.3.2.102-106

Tarmizi, A. H. A., Ismail, R., \& Kuntom, A. (2016). Effect of frying on the palm oil quality attributes-A review. Journal of Oil Palm Research, 28(2), 143-153.

https://doi.org/10.21894/jopr.2016.2802.01

Wai, T. N. K. (2007). Local repeatedly-used deep frying oils are generally safe. International E-Journal of Science, Medicine and Education, 1(2), 55-60.

Wan, T., Rav-Marathe, K., \& Marathe, S. (2016). A Systematic Review on the Kap-O Framework for Diabetes Education and Research. Medical Research Archives, 4(1), 1-21. 
INTERNATIONAL JOURNAL OF ACADEMIC RESEARCH IN BUSINESS AND SOCIAL SCIENCES

Vol. 11, No. 13, Beyond 2021 and COVID-19 - New Perspective in the Hospitality \& Tourism Industry. 2021, E-ISSN: $2222-6990$ ๑ 2021 HRMARS

Wu, M., Lin, P., Pan, C., \& Peng, C. (2019). Risk assessment of personal exposure to polycyclic aromatic hydrocarbons and aldehydes in three commercial cooking workplaces. (November 2018), 1-11. https://doi.org/10.1038/s41598-018-38082-5 